\title{
Esterase-6 locus, a new enzyme polymorphism in Apis mellifera
}

\author{
A Biasiolo *, A Comparini \\ Istituto di Difesa delle Piante dell'Università, p le M Kolbe n 4, 33100 Udine, Italy \\ (Received 10 November 1988; accepted 15 January 1990)
}

\begin{abstract}
Summary - A new polymorphic enzyme locus, esterase-6, has been resolved by electrophoresis in Apis mellifera. Samples from Bologna (Emilia, Italy), representative of $\boldsymbol{A} \boldsymbol{m}$ ligustica, and from North-East Friuli (lialy), regarded as hybrids between $A m$ ligustica and $A m$ carnica, were analyzed. A preliminary population survey shows this locus to be highly variable.
\end{abstract}

Apis mellifera / enzyme polymorphism / esterase-6

\section{INTRODUCTION}

Electrophoretic investigations on geneenzyme systems have shown a very low level of allozyme polymorphism in honey bee populations, possibly related to their haplodiploid condition and/or to eusociality (Sylvester, 1986).

In European populations of Apis mellifera, only 2 loci (malate dehydrogenase-1 and esterase) have shown fairly high variability to-date, and have been used for biochemical-genetic characterization of different races (Badino et al, 1983, 1984, 1985) and for studying their hybridization patterns (Badino et al, 1982; Marletto et al, 1984; Sheppard and McPheron, 1986).
The discovery of other highly variable loci would be very useful for improved genetic characterization of different races or populations of $A$ mellifera.

Bitondi and Mestriner (1983) detected, by electrophoresis, 6 esterase loci in $A$ mellifera; some of them showed a clear allozyme variability. Esterase-3 (Est-3) was used for some of the population genetic research cited above. The more cathodic esterase (Est-6) was perceived to be variable, but allozyme bands were not sufficiently differentiated for reliable genotype classification.

In the course of studies designed to identify markers for genetic characterization of $A$ mellifera from Friuli, regarded as

\footnotetext{
* Correspondence and reprints
} 
a zone of hybridization between $A$ mellifera ligustica and $A$ mellifera carnica (Bolchi Serini et al, 1982; Ruttner, 1988), we obtained a reliable electrophoretic separation of Est- 6 allozyme bands. A preliminary population survey was carried out in samples of $A$ mellifera from Friuli and, for comparison, in a sample of $\boldsymbol{A} \mathrm{m}$ ligustica. The data show that Est- 6 locus is a potential new marker for genetic population studies in A mellifera.

\section{MATERIALS AND METHODS}

Adult workers of $A$ mellifera were sampled, in late summer 1987, from 2 apiaries near Tarvisio (North-East Friuli, Italy) and 1 near Bologna (Emilia, Italy). The latter were supplied by the Istituto Nazionale di Apicoltura, Bologna, as representative of $A m$ ligustica. For each apiary, workers were captured near the entrance of several hives. The samples were stored at $-40^{\circ} \mathrm{C}$ until needed. Five individuals from every hive were used for electrophoresis.

Thorax-head sections of individual bees were homogenized in $0.15 \mathrm{ml}^{\text {buffer }}\left(0.2 \mathrm{~mol}-\mathrm{l}^{-1}\right.$ Tris- $\mathrm{HCl}, \mathrm{pH} 8 ; 0.25$ mmol.1-1 2-mercaptoethanol; 1 mmolol-1 EDTA). Electrophoresis was conducted on the supernatants after homogenate centrifugation. Horizontal electrophoresis was performed in $11.5 \%$ starch gels using, as electrode buffer, 0.18 mol-1-1 Tris-citrate, $\mathrm{pH}$ 7.0, diluted 1:15 in the gel. Electrophoresis was carried out at $250 \mathrm{~V}$ and $5^{\circ} \mathrm{C}$ for $5 \mathrm{~h}$.
The best staining method for Est 6 was the following: the gel slices were immersed in the substrate solution $(1 \mathrm{ml}$ of $0.5 \% \alpha$-naphthylbutyrate in acetone added to $50 \mathrm{ml}$ of 0.05 mol. $\mathrm{H}^{-1}$ Tris- $\mathrm{HCl}, \mathrm{pH} 7.2$ ); after $1 \mathrm{~h}$ of incubation at $38{ }^{\circ} \mathrm{C}$, the substrate solution was removed and replaced with the staining solution $(50 \mathrm{mg}$ of Fast Blue BB salt in $50 \mathrm{ml}$ of $0.05 \mathrm{~mol}^{-1}$ Tris$\mathrm{HCl}, \mathrm{pH}$ 7.2). Est-6 allozyme bands were clearly resolved after $30 \mathrm{~min}$ at $38^{\circ} \mathrm{C}$. Best results were obtained by staining the upper gel slice.

\section{RESULTS AND DISCUSSION}

In Apis mellifera, the esterase electrophoretic pattern is composed of 6 different regions, which have been attributed to the activity of 6 different loci (Bitondi and Mestriner, 1983). Est-6, the most cathodic, exhibited 3 co-dominant alleles in our samples. This enzyme is a monomer, based on heterozygote banding patterns (fig 1).

The Est- 6 genotype distribution of the studied populations of $A$ mellifera well fitted the Hardy-Weinberg expectations, supporting our genetic interpretation for this polymorphism. The allele frequencies are reported in table I. Comparison of allele distribution by contingency tables have shown significant differences among the 3 samples, whether considered together or 2 at a time.

Table I. Est- 6 allele frequencies and heterozygosity values observed (expected) in the analyzed samples of Apis mellifera. $\mathrm{H}=$ heterozygosity; $N=$ number of workers analyzed.

$\begin{array}{llll}\begin{array}{l}\text { Apiary localities: } \\ \text { alleles }\end{array} & \text { Camporosso } & \begin{array}{l}\text { SLeopoldo } \\ \text { (Friuli samples) }\end{array} & \text { Bologna }\end{array}$

\begin{tabular}{lccc}
\hline a & 0.07 & 0.28 & 0.03 \\
$\mathrm{~b}$ & 0.74 & 0.70 & 0.95 \\
$\mathrm{c}$ & 0.19 & 0.02 & 0.02 \\
$N$ & 50 & 50 & 75 \\
$\mathrm{H}$ & $0.42(0.41)$ & $0.36(0.43)$ & $0.11(0.10)$ \\
\hline
\end{tabular}




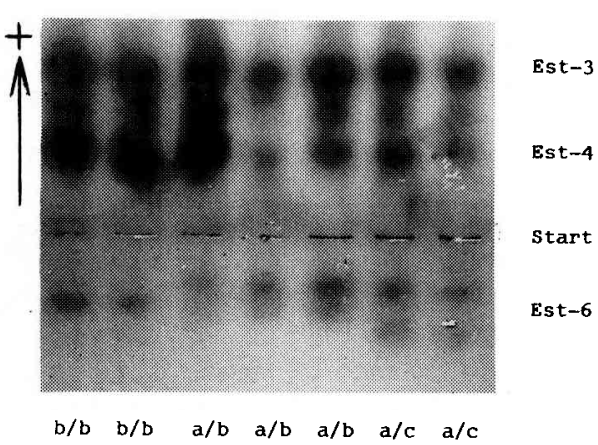

Fig 1. Photograph of some Est-6 electrophoretic patterns and corresponding genotypes, observed in workers of Apis mellifera. Under the staining conditions, overstained bands corresponding to Est-3 and Est-4 loci (Bitondi and Mestriner, 1983) also appear.

The 2 Friuli samples are clearly more variable at Est-6 than the Bologna sample (heterozygosity about 0.4 and 0.1 , respectively). This agrees with the view that Friuli populations of $A$ mellifera might represent hybridization between $A m$ carnica and A m ligustica (Bolchi Serini et al, 1982; Ruttner, 1988).

The Est- 6 polymorphism may aid in the better characterization of different races of $A$ mellifera, particularly $A m$ carnica and $A$ $m$ ligustica. This possibility should be ascertained by extensive studies of Est- 6 variability in $A m$ carnica and $A m$ ligustica populations from areas of endemism.

\section{ACKNOWLEDGMENTS}

We thank the Istituto Nazionale di Apicoltura (Bologna) and Mr M D'Agaro (Istituto di Difesa delle Piante, Udine) for supplying the bee material.

Résumé - Le locus esterase-6, nouveau cas de polymorphisme enzymati- que chez Apis mellifica. Les populations de l'abeille domestique ont montré jusqu'à présent un très faible degré de polymorphisme allozymique. Un nouveau système enzymatique polymorphique, le locus esterase-6 (Est-6), a été mis en évidence chez Apis mellifica par électrophorèse.

Les analyses ont porté sur 15 ruches situées à Bologne (Emilie, Italie), représentatives de la race Apis mellifica ligustica et 20 ruches du nord-est du Frioul (Italie), considérées comme des hybrides de $\boldsymbol{A} \boldsymbol{m}$ ligustica et $A m$ carnica. Cinq ouvrières adultes ont été prélevées dans chaque ruche. L'électrophorèse horizontale sur gel d'amidon a été réalisée sur des coupes individuelles tête-thorax. Le tampon électrode était constitué de tris-citrate à 0,18 molol-1, pH 7,0 dilué à $1 / 15$ dans le gel. Les bandes d'Est- 6 ont été mieux révélées en utilisant l' $\alpha$-naphtylbutyrate comme substrat dans le bain de coloration.

L'Est-6 a présenté dans nos échantillons 3 allèles codominants (fig 1). Les 2 échantillons du Frioul se différencient nettement de celui de Bologne par un taux plus élevé de variabilité de l'Est-6 (tableau I). Le polymorphisme du locus de l'Est- 6 peut contribuer à une meilleure caractérisation des différentes races d'Apis mellifica.

\section{Apis mellifica / polymorphisme enzyma-} tique / estérase-6

Zusammenfassung - Der Esterase-6 Locus, ein neuer Enzympolymorphismus bei Apis mellifera. Die Populationen der Honigbiene haben bisher einen sehr niedrigen Grad von Allozym-Polymorphismen gezeigt. Ein neues polymorphes Gen-Enzym-System, der Esterase-6 Locus (Est-6) wurde durch Elektrophorese bei Apis mellifera eindeutig nachgewiesen.

Es wurden 15 Völker aus Bologna (Emilia, Italien), repräsentativ für Apis 
mellifera ligustica, und zwanzig Völker aus Nordost-Friaul (Italien), die als Hybriden zwischen $\boldsymbol{A} m$ ligustica und $\boldsymbol{A} m$ carnica betrachtet werden können, analysiert. Von jedem Volk wurden fünf erwachsene Arbeitsbienen benutzt. An individuellen Thorax-Kopf-Schnitten wurde eine horizontale Stärkegel-Elektrophorese durchgeführt. Der Elektrodenpuffer war $0,18 \mathrm{M}$ Tris-Citrat, pH 7,0, in dem Gel zu 1:15 verdünnt. Die Est-6-Banden wurden am deutlichsten dargestellt, wenn man $\alpha$-Naphtyl-Butyrat als Substrat in der Färbelösung benutzte.

Est-6 zeigte in unseren Proben drei codominante Allele (Abb 1). Die zwei Proben aus Friaul sind von der Probe aus Bologna deutlich durch den höheren Grad der Variabilität von Est-6 unterschieden (Tabelle I). Der Polymorphismus im Est-6 Locus kann zu einer besseren Charakterisierung der verschieden Rassen von Apis mellifera beitragen.

\section{Apis mellifera I Enzym-Polymor- phismus / Esterase-6}

\section{REFERENCES}

Badino G, Celebrano G, Manino A (1982) Genetic variability of Apis mellifera ligustica
Spin in a marginal area of its geographical distribution. Experientia 38, 540-541

Badino G, Celebrano G, Manino A (1983) Population structure and Mdh-1 locus variation in Apis mellifera ligustica. J Hered 74, 443-446

Badino G, Celebrano G, Manino A (1984) Population genetics of italian honeybee (Apis mellifera ligustica Spin) and its relationships with neighbouring subspecies. Boll Mus Reg Sci Nat (Torino) 2, 571-584

Badino G, Celebrano G, Manino A, Longo S (1985) Enzyme polymorphism in the Sicilian honeybee. Experientia 41, 752-754

Bitondi MMG, Mestriner MA (1983) Esterase isozymes of Apis mellifera : substrate and inhibition characteristics, developmental ontogeny, and electrophoretic variability. Biochem Genet 21, 985-1002

Bolchi Serini G, Sommaruga A, Lapietra G (1982) Studio biometrico di popolazioni alpine di Apis mellifera L. Boll Zool Agrar Bachic Ser II, 17, 1-18

Marletto F, Manino A, Pedrini P (1984) Intergradazione fra sottospecie di Apis mellifera $L$ in Liguria. Apic Mod 75, 159-163

Ruttner F (1988) Biogeography and taxonomy of Honeybees. Springer-Verlag, Berlin Heidelberg

Sheppard WS, McPheron BA (1986) Genetic variation in honey bees from an area of racial hybridization in western Czechoslovakia. Apidologie 17, 21-32

Sylvester HA (1986) Biochemical genetics. In: Beo Genetics and Breeding (Rinderer TE, ed) Academic Press, Orlando, 177-203 